\title{
Lake water and talik groundwater interaction in continuous permafrost, Central Yakutia
}

\author{
Nadezhda Pavlova ${ }^{1, *}$, Liudmila Lebedeva ${ }^{1}$, and Vladimir Efremov ${ }^{1}$ \\ ${ }^{1}$ Melnikov Permafrost Institute SB RAS, Merzlotnaya 36 677010, Yakutsk, Russia
}

\begin{abstract}
Structural features of a lake talik associated with eolian relief are discussed. Analysis of hydrochemical and hydrological data for 20102017 showed that talik groundwater feeds lake and maintains perennial outflow from the lake. Variations in the chemical composition of the lake and outflowing creek are characterized on an annual and interannual basis. Seasonal comparison of hydrochemical data indicates a downward trend in dissolved-solids content of the lake water over the last six years, suggesting an increasing contribution of suprapermafrost groundwater to the lake and lake talik. Probable reason of enhanced suprapermafrost flow is increase of its duration due to observed rise of winter air temperature.
\end{abstract}

\section{Introduction and study site}

Most of the taliks in continuous permafrost environment are associated with rivers and lakes. River channel taliks are the most widely studied ones in Siberia [1,2]. There are more than 700000 lakes in Yakutia. Lake taliks and their interactions with surface water and permafrost are not characterized by field-based data and are poorly understood.

At the Lena-Aldan interfluve lakes with high-quality talik water are associated with vegetated stable dune massifs. Hypothesis suggests that such lakes are feeded by groundwater of subaerial suprapermafrost and intrapermafrost talik aquifers. To check this hypothesis study of hydrogeology and permafrost system of lake Unugestyakh watershed was performed. The study site is located within the Bestyakh Terrace of the Lena River with elevations ranging from 120 to $160 \mathrm{~m}$ a.s.l. Permafrost thickness varies from 200 to $400 \mathrm{~m}$. Rather narrow elongated vegetated sandy ridges $2-10 \mathrm{~m}$ high and fluvial depressions with 10-20 km length are typical landforms in the terrace. Shallow (3.5-4.0 m deep) lakes could be found at depressions.

The nearest meteorological station Pokrovsk is located $20 \mathrm{~km}$ to west of the study site. Mean annual air temperature is $-9.5^{\circ} \mathrm{C}$ and precipitation is $260 \mathrm{~mm} /$ year.

Low part of the Bestyakh terrace is formed by alluvial sand and gravel. Main part is formed by periglacial alluvia [3] that are overlaid by aeolian formations. Quaternary deposits with total thickness of 20-86 m underlaid by Cambrian limestones in southern part of the Bestyakh terrace and by Jurassic sandstone in its northern part. Cambrian limestones sink under Jurassic sandstone towards north.

\footnotetext{
* Corresponding author: napavlova@mpi.ysn.ru
} 
Subaerial and intrapermafrost talik aquifers are widespread phenomenon in upper part of geological section of the southern part of the Bestyakh terrace [4, 5]. Taliks lower aquitard is Cambrian perennially frozen deposits, upper one is Quaternary sediments that are frozen up to the 15-50 m depth. Lakes of the Bestyakh terrace and lake taliks have hydraulic connection with intrapermafrost groundwater aquifer [4, 6-8]. Groundwater discharge occurs through a series of springs along the foot of the Bestyakh terrace, as well as in the valleys of the Lena River tributaries (fig. 1). Part of the supra-intrapermafrost groundwater is discharged into lakes as subaqueous springs. The object of the current study is lake Unugestyakh and lake talik shown at the Fig.1.

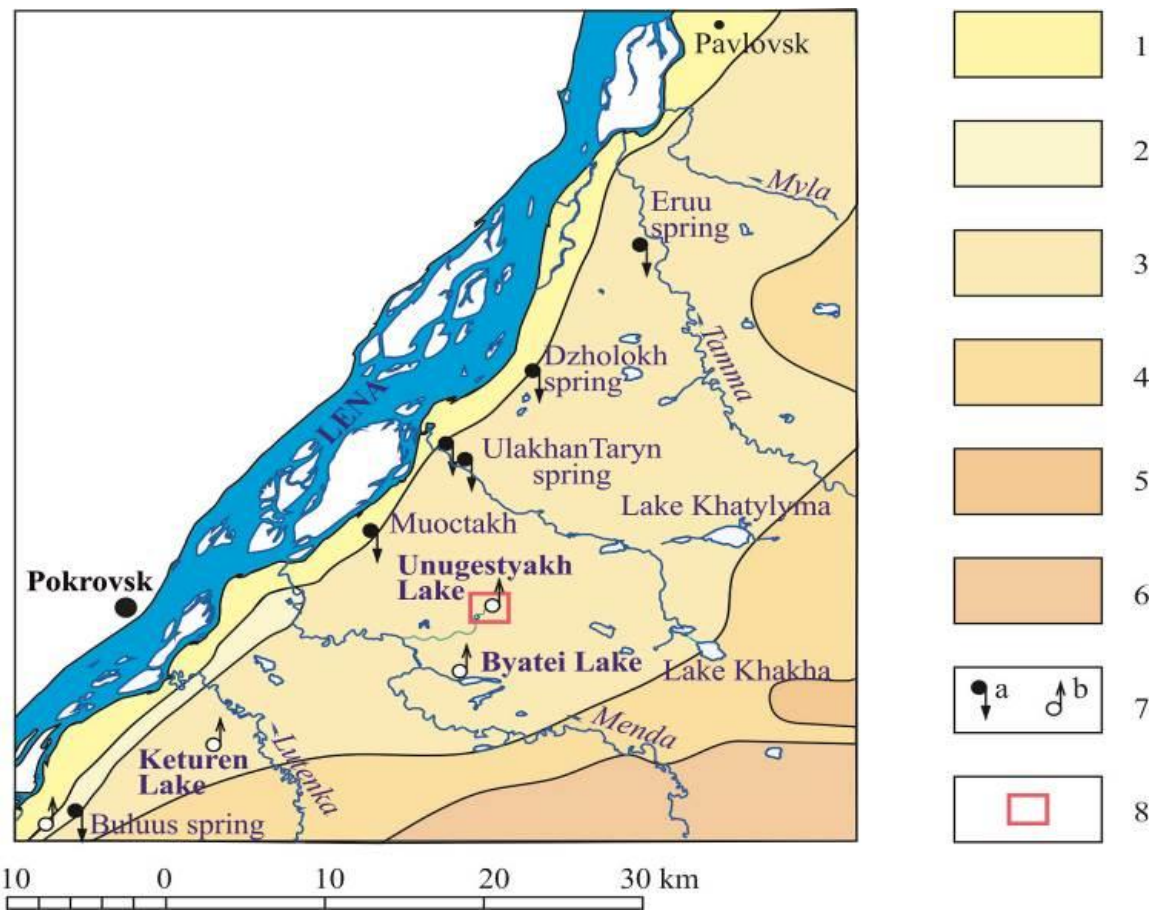

Fig. 1. Location of the springs of supra- and intrapermafrost groundwater in the middle part of the Lena River terrace. 1 - Low accumulative terrace; 2-6 - Medium-altitude accumulative-erosion terraces: 2 Kerdem, 3 - Bestyakh, 4 -Tyungyulyu, 5 - Abalakh, 6 - Magan; 7 - Spring with subarial (a) and subaquatic (b) discharge; 8 - Research site.

\section{Methods}

The geology of the study area was described based on the data from a borehole drilled by the Yakutsk Exploratory Expedition in 2004 near the lake basin (fig. 2). Suprapermafrost water of the active layer was sampled from pits. Intrapermafrost water was sampled from the borehole. In 2010-2017, fieldwork included discharge measurements in the outflowing creek and surface water sampling conducted during the winter low-flow period (MarchApril) and in the fall (September-October) before lake freeze-up. Occasionally discharge measurements and water sampling were made during the summer.

Water samples were analysed at the Melnikov Permafrost Institute using titration and capillary electrophoresis methods (analysts L.Y. Boitsova and O.V. Shepeleva) and at the Analytical Certification Test Centre, Institute of Microelectronics Technology and HighPurity Materials RAS (Chernogolovka) using mass spectrometry (ICP-MS) and inductively coupled plasma atomic emission spectroscopy (ICP-AES). 


\section{Results and discussion}

Unugestyakh Lake (vice versa) is nearly round in shape and reaches $0.7 \times 0.9 \mathrm{~km}$ in size (fig. 2). Its bottom is funnel-shaped. The maximum water depth in summer is $4 \mathrm{~m}$ in the centre and 1.3-1.5 $\mathrm{m}$ at $50 \mathrm{~m}$ from the shore. Despite low precipitation and absence of the surface inflow, the lake does not show any evidence of drying. The lake is surrounded by a 30 to $150-\mathrm{m}$ wide strip of larch and birch forest, behind which there is thin pine forest with traces of fire. Slopes of the lake basin are gentle. The catchment area is about $12 \mathrm{~km}^{2}$.

A perennial creek flows out of lake Unugestyakh to the south. Close to the outflow, open water is maintained during the whole winter despite low temperature of water (0$0.5^{\circ} \mathrm{C}$ ) and air (up to $-60^{\circ} \mathrm{C}$ ). An icing is formed downstream in the Unugestyakh Creek.

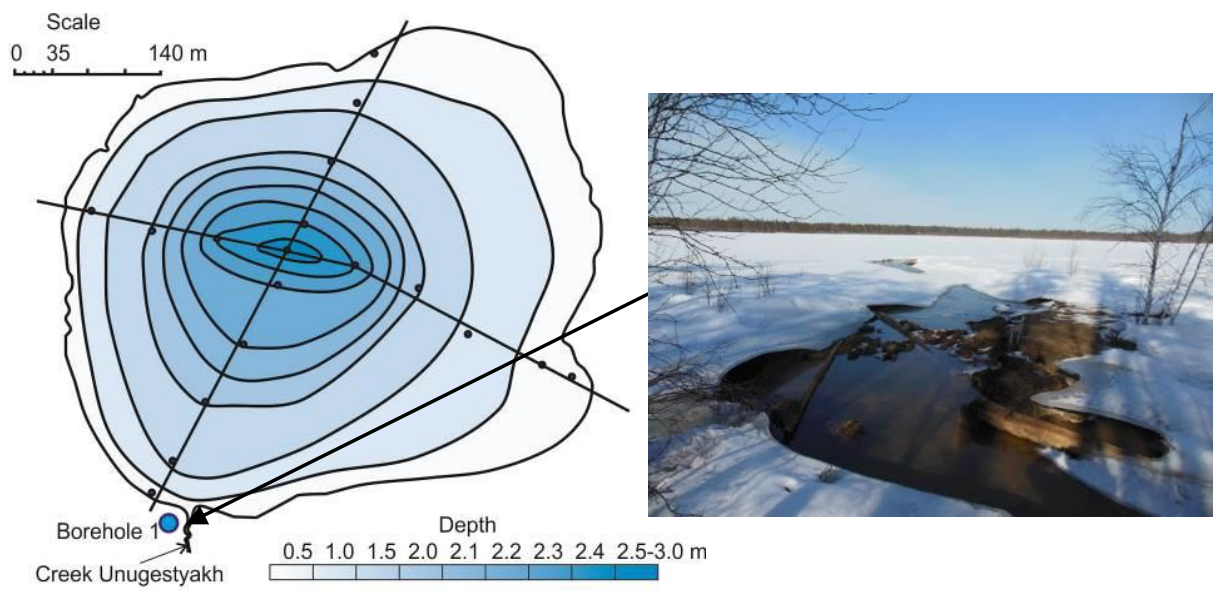

- Point of depth measurement

Fig. 2. Relief scheme of the Unugestyakh lake bottom and photo of open water in the outflow creek (March 2013).

Within the Unugestyakh Lake basin, Quaternary deposits are underlain by Middle Cambrian limestone at $37 \mathrm{~m}$ depth. Thaw depths vary from $3 \mathrm{~m}$ on the gentle sand slopes to $1.5 \mathrm{~m}$ near Unugestyakh Lake. Sands have very low moisture contents (2-6\%) in the upper part of the geological section, increasing to full saturation near active layer base (15-20\%). Suprapermafrost subaerial taliks, 6 to $10 \mathrm{~m}$ in thickness, are occasionally found in the lake's catchment area.

A hydrogenic talik is present beneath lake Unugestyakh with a thickness more than 100 $\mathrm{m}$. The talik is overlain by permafrost to a depth of $24 \mathrm{~m}$ along the lake margin. In a borehole drilled in the lake basin water level of the Quaternary aquifer established at $1.5 \mathrm{~m}$, while the level of the Cambrian aquifer rose $0.8 \mathrm{~m}$ above the ground surface. Such ratio of the levels indicates confining conditions and upward flow in the talik: from the Cambrian rocks to the Quaternary aquifer and through the sand deposits to lake Unugestyakh.

Analysis of the Unugestyakh creek flow data covering 7 years indicates that the total groundwater discharge to the lake based on winter low flows is close to $4500 \mathrm{~m}^{3} / \mathrm{day}$. Considering the difference in head between the Quaternary and Cambrian aquifers, as well as the hydraulic characteristics of the sands, the discharge of intrapermafrost water to the lake through the underlying talik is estimated to be $2500 \mathrm{~m}^{3} /$ day. Hence, suprapermafrost water accounts for about $2000 \mathrm{~m}^{3} /$ day of the winter outflow from Unugestyakh Lake.

The mixing of waters of different origin in the lake talik is supported by the hydrochemical data (table). All sampled waters are of the bicarbonate class. The 
groundwater circulating in the Cambrian aquifer is more mineralized (Table), with sodium ( $47 \%$ of the sum of major cations) and magnesium $(36 \%)$ dominating the cation composition. The groundwater of the Quaternary aquifer contains $0.2 \mathrm{~g} / \mathrm{dm}^{3}$ dissolved solids, with the composition dominated by magnesium (36\%) and calcium (56\%) ions. The suprapermafrost water of the active layer is ultrafresh, mixed-cation type. The chemical composition of the Cambrian groundwater systems is stable seasonally and from year to year.

Table. Chemical composition of water at the Unugestyakh site, $\mathrm{mg} / \mathrm{L}$.

\begin{tabular}{|c|c|c|c|c|c|c|c|c|c|c|c|c|}
\hline $\begin{array}{c}\text { Sampling } \\
\text { date }\end{array}$ & Ca2+ & Mg2 + & Na+ & K+ & HCO3-CO32-SO42- & Cl- & TDS & pH & Sr & Eh, mv \\
\hline \multicolumn{10}{|c|}{ Borehole 1, Cambrian aquifer, interval 37-100 m } \\
\hline 21.08 .2004 & 22.5 & 26.3 & 60.0 & 3.5 & 378.2 & 0.0 & 1.7 & 4.1 & 501.4 & 7.9 & 5.51 & n.d. \\
\hline \multicolumn{10}{|c|}{ Borehole 1, Quaternary aquifer, interval 24-37 m } \\
\hline 02.07 .2004 & 29.5 & 11.5 & 11.6 & 1.2 & 189.1 & 0.0 & 2.7 & 3.4 & 207.1 & 7.6 & 0.22 & 183 \\
\hline \multicolumn{10}{|c|}{ Suprapermafrost water of the active layer } \\
\hline 22.06 .2012 & 2.9 & 1.6 & 2.4 & 0.7 & 27.4 & 0.0 & 1.6 & 0.5 & 37.5 & 5.6 & 0.06 & 570 \\
\hline 30.09 .2012 & 5.2 & 1.4 & 2.0 & 1.5 & 21.2 & 0.0 & 1.6 & 1.0 & 34.7 & 6.0 & n.d. & 433 \\
\hline \multicolumn{10}{|c|}{ Unugestyakh Creek } \\
\hline 28.03 .2012 & 38.0 & 16.0 & 9.0 & 1.0 & 222.2 & 0.0 & 4.9 & 1.4 & 298.8 & 7.0 & 0.31 & n.d. \\
\hline 21.06 .2012 & 19.6 & 7.8 & 4.5 & 0.2 & 93.5 & 6.6 & 1.6 & 1.2 & 135.3 & 8.8 & 0.18 & n.d. \\
\hline 30.09 .2012 & 31.2 & 11.3 & 5.0 & 0.4 & 115.6 & 14.4 & 0.7 & 1.0 & 179.7 & 8.7 & n.d. & 383 \\
\hline 19.03 .2016 & 32.7 & 17.0 & 6.0 & 1.20 & 212.9 & 0.0 & 0.2 & 0.8 & 272.2 & 7.0 & 0.32 & 230 \\
\hline 22.06 .2016 & 20.9 & 7.5 & 3.4 & 0.40 & 54.1 & 28.6 & 0.3 & 0.1 & 115.8 & 9.1 & 0.08 & 412 \\
\hline 06.09 .2016 & 17.6 & 6.11 & 3.0 & 0.30 & 93.7 & 2.85 & 0.1 & 0.2 & 124.0 & 9.3 & 0.20 & 409 \\
\hline 24.03 .2017 & 39.4 & 10.0 & 6.5 & 1.20 & 194.7 & 0.0 & 0.2 & 0.4 & 254.2 & 7.0 & 0.32 & 220 \\
\hline
\end{tabular}

Note: n.d. - not determined.

TDS concentration of water in the lake and outflowing creek varies seasonally, but the relative amounts of major cations remain stable throughout the year. The content of calcium ions is $51-52 \%$ and that of magnesium ions is $30-35 \%$. TDS concentrations in the lake and creek are lowest $\left(0.1 \mathrm{~g} / \mathrm{dm}^{3}\right)$ during snowmelt. In summer evaporation causes some increase of TDS concentration of the surface water. Maximum TDS concentrations of the lake and creek water $\left(0.3 \mathrm{~g} / \mathrm{dm}^{3}\right)$ are observed by the end of the winter due to predominance of the intrapermafrost groundwater contribution. In March-April, increased strontium contents in the surface water confirm that groundwater from the Cambrian aquifer, which is characterized by high concentrations of strontium, contributes to the lake. 


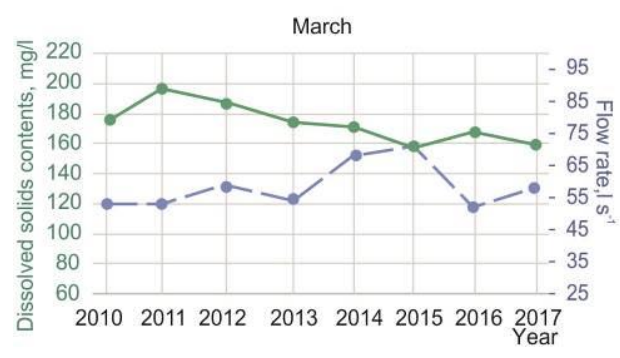

$\rightarrow$ Dissolved solids contents $\rightarrow-$ Flow rate

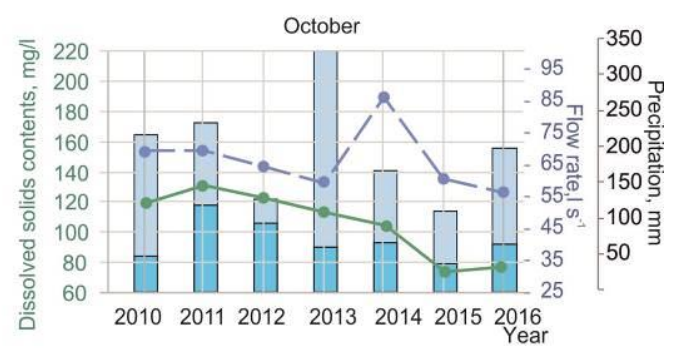

Precipitation: May-July

Precipitation: August-September

Fig. 3. Variation of TDS concentration and flow of the Unugestyakh creek.

Data shows a decrease of TDS concentrations of the Unugestyakh Creek for both fall and winter over the period 2010-2016 (Fig. 3). Comparison of the fall values of TDS concentration and flow rate with total rainfall has revealed no correlation between them. The interannual variation of October TDS concentrations was found to agree with the rainfall of preceding two months (August-September). Similar values of the Unugestyakh creek streamflow in the end of the winter and June suggest absence of surface and suprapermafrost flow to the lake in beginning of summer season. Suprapermafrost water flow to lake and talik is restricted by shallow active layer in the beginning of summer.

The winter TDS concentration and discharge rate in the creek show an inverse relationship: the greater is the outflow from the lake, its TDS concentration is lower. Low variation of flow and significant decrease of TDS concentration of the Unugestyakh creek water for 2010-2017 suggest that in winter suprapermafrost groundwater contribution to the lake have been increased and intrapermafrost water fraction have been decreased.

\section{Conclusion}

Lakes with continuous outflow and indicating subaqueous springs are found in the southern part of the Bestyakh Lena River terrace and associated with aeolian sediments underlaid by Cambrian carbonate deposits. Chemical composition of lake and talik waters is formed by mixing of groundwater of different genesis. The Cambrian aquifer groundwater is more mineralized $\left(0.5 \mathrm{~g} / \mathrm{dm}^{3}\right)$, with sodium and magnesium dominating the cation composition. The groundwater of the Quaternary aquifer (TDS $0.2 \mathrm{~g} / \mathrm{dm}^{3}$ ) dominated by magnesium and calcium ions. The active layer suprapermafrost water is ultrafresh $\left(0.03-0.04 \mathrm{~g} / \mathrm{dm}^{3}\right)$, mixed-cation type. The Quaternary aquifer acts as a buffer linking the groundwater of the Cambrian aquifer, the suprapermafrost water of the active layer and the surface lake water. Decrease of Unugestyakh creek TDS concentration in recent years suggests increase of fraction of suprapermafrost groundwater flow to lake and talik.

Acknowledgements. Authours are thankful to Lyudmila Boitcova and Olga Shepeleva for chemical analysis. The study is partly supported by RFBR, projects No 17-05-00926 and 18-45-140065.

\section{References}

1. I.A. Nekrasov, Taliks od flooplains and principles of their distribution. Moscow Nauka, 138, (1967) (in Russian)

2. V.M. Mikhailov, Floodplain Taliks of Northeast of Russia. Geo Publishers, Novosibirsk, 244, (2013) (in Russian) 
3. V.A.Kamaletdinov, P.S. Minuk, Bulletin of comission of Quaternary research Structure and characteristics of sediments of the bestyakh terrace of the middle Lena River, 60, 68-78 (1991) (in Russian)

4. N.P. Anisimova Cryohydrogeochemical characteristics of permafrost, 153 (1981) (in Russian)

5. A.V. Boytsov, In: Groundwater Monitoring in Cryolithozone. Regime of springs and suprapermafrost and intrapermafrost groundwater ,76-89 (2002) (in Russian)

6. A.I. Efimov, In: Studies of permafrost in Yakut Republic.Ulakhan-Taryn perennial freshwater spring in Central Yakutia Moscow, 3, 60-105 (1952) (in Russian)

7. A.V. Boytsov, Fresh prings regime in Central Yakutia in relation to environmental problems of transportation construction. In: Cryolithozone and ground water in Siberia. Part 2. Ground water and aufeis, 46-62 (1996) (in Russian)

8. N.A. Pavlova, A.B. Kolesnikov, V.S. Efremov, V.V. Shepelev, Groundwater chemistry in intrapermafrost taliks in Central Yakutia. Water Resources, 43 (2), 353363 (2016) 